\title{
Opowieść o jesieni jako rite de passage. Rola scenariuszy kultury w oswajaniu choroby nowotworowej $\mathrm{u}$ dzieci
}

Można powiedzieć, że najbardziej tajemnicza nie jest ciemna, głęboka noc, ale samo południe, kiedy wszystkie rzeczy ukazują się w pełnym świetle oczywistości, gdy obnaża się sam fakt ich istnienia.

Vladimir Jankelevitch

Obrazowe porównanie życia i śmierci jako nieuchronnego cyklu następującej po dniu nocy to jedna z niezliczonych metafor ludzkiego życia. Metaforyczne ujęcia tego niełatwego tematu są szeroko eksploatowane w poezji, literaturze popularnej, naukowej, jak i w codziennej komunikacji. Jednym z przykładów wykorzystania są baśnie i bajki dla dzieci. W artykule skupiono się nad rezultatami wykorzystania bajek terapeutycznych $\mathrm{w}$ rozmowach $\mathrm{z}$ dziećmi chorymi terminalnie i objętymi opieką paliatywną. Analizą objęto bajki, w których można odszukać metaforyczne ujęcie śmierci i umierania realizujące się poprzez scenariusz przebudzenia. W perspektywie teoretycznej inspiracją była teoria scenariuszy kultury stworzona przez medioznawcę Aleksandra Woźnego.

Obserwując współczesne społeczeństwo, kulturę czy zawartość mass mediów, można pokusić się o stwierdzenie, że ludzie starzy, pomarszczeni, schorowani nie mają dziś racji bytu. Sukces i pełnię szczęścia mogą osiągnąć tylko piękni i młodzi. Tematy takie 
jak starość, choroba, śmierć i umieranie są wyraźnie tabuizowane. Usiłuje się o nich nie mówić, a jeśli już się mówi, to najczęściej w negatywnym kontekście. Próbujemy się oszukać, że będziemy zawsze piękni i młodzi, a starość to „problem”, który nas nie dotyczy. „Zapominamy, że życie jest kruche, delikatne, że nie trwa wiecznie. Zachowujemy się wszyscy, jakbyśmy byli nieśmiertelni”'.

Paradoksalnie — jednocześnie stajemy się świadkami globalnego starzenia się społeczeństw. Profesjonalizacja medycyny, rosnąca świadomość konsumentów tudzież coraz większa liczba propagatorów trendu świadomego odżywiania i dbania o zdrowie przekłada się na coraz dłuższe życie. Według danych prognostycznych opracowanych przez Główny Urząd Statystyczny do roku 2050 drastycznie zmniejszy się liczba dzieci i osób dorosłych, w zamian znacząco wzrośnie liczba i udział osób w wieku co najmniej 60 lat i więcej ${ }^{2}$. Mogłoby się wydawać, że w społeczeństwie poszukującym lekarstwa na nieśmiertelność spadek umieralności jest rzeczą zadowalającą. Należy jednak zauważyć, że wraz z wiekiem spada wydolność ludzkiego organizmu, pojawia się coraz więcej ograniczeń fizycznych oraz liczne choroby.

Alarmujące są najnowsze dane i prognozy dotyczące nowotworów. Antropolog Hubert Wierciński przytacza dane Światowej Organizacji Zdrowia, według których na początku millenium powodem ok. $13 \%$ wszystkich zgonów w skali globalnej były choroby onkologiczne. Do końca 2020 roku liczba ta może się podwoić, a statystyki pokazują, że ludzie chorują coraz częściej i w coraz młodszym wieku ${ }^{3}$. Wierciński pisze dalej, że na poziomie społecznym explicite zauważalne jest piętnowanie i marginalizowanie osób chorych onkologicznie, a także wyraźna tabuizacja ich problemów i doświadczeń ${ }^{4}$. Choroba i umieranie są wstydliwie ukrywane w szpitalach i hospicjach, bo większość z nas woli przyznawać się do „lepszego świata zdrowych [...] śmierć stała się dla nas faktem upokarzająco bezsensownym, choroba powszechnie utożsamiana ze śmiercią odbierana jest jako coś, co należy ukrywać" 5 .

\section{W chorym ciele chory duch (?) - współczesna rola antropologii medycznej}

Choroba staje się zjawiskiem już nie tylko medycznym polegającym na zaburzeniu homeostazy organizmu. Coraz częściej staje się ona problemem interdyscyplinarnym poruszanym przez nauki humanistyczne czy społeczne. Rosnącego znaczenia

\footnotetext{
${ }^{1}$ É.E. Schmitt, Oskar i pani Róża, przeł. B. Grzegorzewska, Kraków 2017, s. 27.

2 Prognoza ludności na lata 2014-2050, Główny Urząd Statystyczny, Warszawa 2017, s. 20-22, http:// stat.gov.pl/ (dostęp: 20.07.2018).

${ }^{3}$ H. Wierciński, Rak: antropologiczne studium praktyk i narracji, Warszawa 2015, s. 7.

${ }^{4}$ Ibidem, s. 9.

${ }^{5}$ S. Sontag, Choroba jako metafora; AIDS i jego metafory, przeł. J. Anders, Kraków 2016, s. 10.
} 
nabiera rozwijająca się na polskim gruncie badawczym subdyscyplina antropologii kultury - antropologia medyczna, która, zajmując się badaniem zagadnień zdrowia i choroby w kulturze stanowi dopełnienie biomedycyny. „Stawia sobie za cel odkrycie, w jaki sposób wiedza medyczna funkcjonuje poza światem lekarzy i na-

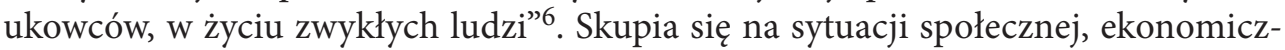
nej oraz prawnej chorych, a także koncentruje się na pojmowaniu i doświadczaniu przez nich choroby. Badacze zastanawiają się także nad tym, jak styl życia wpływa na zdrowie i czym ów stan jest dla poszczególnej jednostki. Choroby, a zwłaszcza onkologiczne, są nie tylko schorzeniem czy niedomaganiem pojmowanego biologicznie organizmu, to także zjawisko społeczne, które wpływa na różne poziomy życia. Wierciński wprost stwierdza, że „rak to zjawisko balansujące między tym, co lokalne i indywidualne, a tym co globalne i wspólne"7. Choroba stała się więc zjawiskiem de facto kulturowym, a zdrowie jest pojęciem bardzo subiektywnym, mającym odrębne znacznie w różnych kulturach.

Antropologia medyczna stanowi holistyczne podejście do człowieka jako jednostki złożonej z dotkniętego chorobą organizmu (pole zainteresowań biomedycyny), ale także pozwala poznać subiektywne doświadczenie schorzenia i jego wpływ na mentalny (autoidentyfikacja) i społeczny obraz człowieka. W trawestacji popularnej sentencji odzwierciedla się przesłanie antropologii medycznej, która podkreśla konieczność dostrzegania w chorym nie tylko jego ciała, ale także i duszy — od wieków bowiem wiadomo, że „,w zdrowym ciele, zdrowy duch”. Protagonistą takiego podejścia był Michel Foucault, który zarzucał biomedycynie ekspansywność i niszczycielski wpływ na kultury lokalne. Postępującą medykalizację społeczeństwa postrzegał nawet w kategoriach władzy, która reguluje życie obywateli, jednocześnie ich uprzedmiatawiając. Byron Good wykazał, że choroba sama w sobie reprezentuje aspekt kulturowy poprzez towarzyszący jej zespół znaczeń i symboli. Jest to zjawisko, które poprawnie można zrozumieć dzięki interpretacji kulturowej, a uwarunkowane kulturowo i społecznie znaczenie musi zrozumieć w takim samym stopniu zarówno lekarz, jak i antropolog. Jego zdaniem biomedycyna błędnie opierała się na redukcjonistycznym sposobie myślenia o ciele i człowieku, które zakładało, że objawy zgłaszane przez chorych to zjawiska obiektywne. Badania Gooda wykazały, że choroba i jej symptomy to przede wszystkim rozbudowane metafory o podłożu społecznym i kulturowym. Kamieniem milowym w antropologii medycyny było dzieło Atwooda Gainesa i Roberta Hahnema Physicians of Western Medicine (1985), które jest próbą zbliżenia środowiska praktyków nauk społecznych i świata lekarzy. Autorzy udowodnili, że lekarze muszą brać pod uwagę także problemy tradycyjnie należące do kompetencji humanistyki ${ }^{8}$.

${ }^{6} \mathrm{H}$. Wierciński, Stosowana antropologia medyczna, czyli co antropolog może dać lekarzowi, [w:] Antropologia stosowana, Warszawa 2013, s. 338.

${ }^{7}$ H. Wierciński, Rak..., s. 8.

${ }^{8}$ Ibidem, s. 23-25. 
Interdyscyplinarna metoda o podłożu antropologicznym łączy w sobie subiektywny aspekt kulturowy medycyny (różny w każdej kulturze) oraz aspekt stricte medyczny. Najprostszym zobrazowaniem tego podejścia może stać się przykład rozumienia i doświadczania dowolnej choroby, np. grypy. Medycznie będzie to wirusowa choroba przenoszona drogą kropelkową o takich a takich objawach - podobne objawy będzie miał Europejczyk i Afrykańczyk. Zupełnie inne będzie jednak subiektywne pojmowanie swego stanu przez tych dwóch chorych.

Kompleksowe podejście do choroby i chorowania jest podstawą jednej z najważniejszych koncepcji antropologii medycznej - wyróżnienia kategorii illness, disease oraz sickness. Podział na illness i disease wprowadził Horacio Fabrega. Redefinicji tego podejścia dokonał Arthur Kleinman - lekarz psychiatra i antropolog, który uznał, że obydwa terminy oddają stan wynikający z lokalnego kontekstu kulturowego, który określił jako „lokalny system zdrowia”, dodając do nich sickness, a więc społeczny sens choroby. Kleinmann w swoich badaniach wykazał, że każdy taki lokalny system jest tworzony przez właściwe sobie źródła wiedzy i poziomy racjonalności. Według badacza postrzeganie oraz interpretacja stanu zdrowia i choroby to wypadkowa wzajemnie przenikających się treści „popularnych” oraz „profesjonalnych”. Wynikał z tego fakt, że disease to nie obiektywny stan, lecz interpretacja illness dokonana przez profesjonalistę wskutek nałożenia specjalistycznej taksonomii na wypracowane normy i reguły wiedzy. Sickness to w jego teorii choroba w znaczeniu ogólnym, illness to jej rozumienie przez pacjenta, a disease przez lekarza ${ }^{9}$. Illness i disease, bardzo często są diametralnie różnie. Nierzadko dla lekarza pacjent jest tylko jednostką chorobową, którą trzeba przywrócić do stanu zdrowia. Schorzeniem, które trzeba wyleczyć, a nie osobą, która oprócz przywrócenia somatycznego stanu zdrowia, szuka także uleczenia. Powrót do hipokratejskiego wymiaru medycyny, gdzie salus aegroti suprema lex ${ }^{10}$, jest zadaniem dla współczesnej antropologii medycznej.

\section{Wyrazić niewyrażalne — rola metafor w rozmowach o śmierci}

"Choroba jest nocną stroną życia, naszym bardziej uciążliwym obywatelstwem. Od dnia narodzin każdy z nas posiada jakby dwa paszporty — przynależy zarówno do świata zdrowych, jak i do świata chorych. I choć wszyscy wolimy przyznawać się tylko do lepszego z tych światów. Prędzej czy później, chociażby na krótko musimy uznać również nasz związek z tym drugim" ${ }^{\prime 1}$.

9 Ibidem, s. 25.

10 „Salus aegroti suprema lex” czyli „dobro pacjenta najwyższym prawem” to maksyma, określanego ojcem medycyny Hipokratesa, która (przytaczana w oryginalnej pisowni łacińskiej) jest także jedną z głównych zasad etycznych w Kodeksie Etyki Lekarskiej.

11 S. Sontag, op. cit., s. 5. 
Metaforyczne ujęcie choroby jest wstępem do monografii Susan Sontag Choroba jako metafora. AIDS i jego metafory. Pozycja wydana prawe pół wieku temu nie traci na swej aktualności. Wręcz przeciwnie. „Trudno dziś sobie wyobrazić mówienie o śmierci inaczej jak tylko ściszonym głosem, z wymalowanym na twarzy zabobonnym lękiem” ${ }^{2}$. „Metafory są centralnym składnikiem codziennego posługiwania się językiem, a co więcej wpływają na nasz sposób postrzegania, myślenia i działania"13. Sontag przedstawia zaczerpnięte $\mathrm{z}$ wojskowego żargonu liczne metafory, którymi przyjęło się mówić o chorobie.

Jednym z najczęstszych porównań jest pojmowanie choroby jako kary. Tego typu metafory mają długą historię (Sontag odnajduje je już w Iliadzie i Odysei) i są szczególnie żywe w odniesieniu do raka, którego określa jako jedno ze schorzeń „spektakularnie spowite w kostium metafory”. Ciało to „forteca”, którą „atakują” choroby, a proces leczenia ukazywany jest jako wojna. Choroba to „cos'” obcego, „wróg z zewnątrz”, „obcy”, „barbarzyńca”, który toczy „wojnę” ze swoją „ofiarą” - ciałem, natomiast raka nazywa wprost "mordercą". Wpisanie choroby w tę matrycę pejoratywnych skojarzeń powoduje, że schorzenia terminalne stają się "zaraźliwe moralnie”, a społeczeństwo obawia się kontaktu z chorymi. Rak nosi znamiona wyroku. Tak długo jak będzie on traktowany jako podły, niezwyciężony drapieżnik, a nie po prostu jako choroba, większość cierpiących na raka ludzi rzeczywiście będzie upadała na duchu ${ }^{14}$. Negatywne metafory samej choroby przekładają się na podobny metaforycznie odbiór hospicjów, które w tym rozumieniu są „gettem”, zbiorowiskiem ofiar wykluczonych ze społeczeństwa. Nazwanie hospicjum „umieralnią”, nikogo nie dziwi, a poddanie się pod jego opiekę uznawane jest za ostateczność. Nie ma logicznej argumentacji tłumaczącej wiele stereotypów, a wspomniana pejoratywna metaforyka raka oraz społeczny wizerunek hospicjum negatywnie wpływają na proces leczenia i samopoczucie pacjentów.

Trudność podjęcia się rozmów na tematy ostateczne sprawia, że jeśli już próbuje się podjąć tematykę śmierci oraz prowadzącej ku niej chorobie, przedstawia się je bardzo często za pomocą metafory. „Kulturowa i społeczna ucieczka od śmierci i przed śmiercią ma swoje konsekwencje wychowawcze. [...] wychowanie bezwiednie przyczynia się tym samym do przyzwolenia na lekceważenie śmierci jako doświadczenia egzystencji, pozostawiając jej co najwyżej materialny wymiar" ${ }^{15}$. Wielu rodziców sądzi, że dziecko powinno stykać się jedynie z rzeczywistością świadomości i obrazami, które sprawiają przyjemność, jednocześnie unikając wszystkiego, co może stanowić jego udrękę. Dorośli starają się ukrywać dwoistość ludzkiego życia

12 A. Wilowski, Weź, pokochaj smoka. Rzecz o umieraniu dzieci, Warszawa 2004, s. 19.

13 G. Lakoff, M. Johnson, Metafory w naszym życiu, przeł. T.P. Krzeszowski, Warszawa 1988, s. 6.

14 S. Sontag, op. cit., s. 8.

15 A. Naumiuk, O śmierci w procesie wychowania, [w:] Prawda umierania i tajemnica śmierci, red. M. Górecki, Warszawa 2010, s. 178-179. 
— to, że ma ono nie tylko jasne strony ${ }^{16}$. W obawie o dziecięcą psychikę, unikają wkraczania w tę swoistą sferę sacrum, udając, że tematu nie ma. O sprawach ostatecznych najtrudniej rozmawiać z dziećmi chorymi przewlekle i terminalnie, zwłaszcza gdy takie rozmowy trzeba przeprowadzać w hospicjach. Nieukształtowana w pełni dziecięca psychika, doświadczanie postępującej choroby, niepewność kolejnego dnia sprawiają, że dziecko narażone jest na permanentny strach przed śmiercią, jeszcze głębiej ją przeżywając.

Pedagogowie i psycholodzy zastanawiają się nad tym jak, i czy w ogóle, dzieci rozumieją śmierć. Czy są świadome swojej choroby i nieuchronnego końca ${ }^{17}$, czy rozmawiać z nimi na tematy ostateczne i czy należy przekazać im prawdę o diagnozie. Przywoływany jako wzór osoby towarzyszącej dziecku w sytuacji śmierci - Janusz Korczak wskazywał na niezaprzeczalne prawo dziecka do śmierci, podkreślając, że obowiązkiem dorosłego opiekuna jest zrozumienie przeżywanych przez dziecko emocji oraz przygotowanie do takiej sytuacji, tzn. przedwczesnej śmierci ${ }^{18}$. Obecnie powszechne jest przekonanie, że małe dzieci nie znają lęku przed śmiercią i nie są świadome jej istnienia. Ograniczone są także badania rozumienia i przeżywania śmierci przez najmłodszych. Przyczyny tego stanu Kędzierska upatruje w przyjęciu badawczego założenia, że dzieci posiadają mało rozwinięte zdolności komunikacyjne oraz że nie mają zdolności myślenia abstrakcyjnego, a więc nie rozumieją, czym jest śmierć (zakłada się więc, że jej nie przeżywają). Nie są w stanie zrozumieć, że jest ona nieodwracalna. Istotna jest także trudność doświadczania lęków związanych z własną śmiertelnością przez dorosłych oraz ich naturalna potrzeba chronienia dziecka przed potencjalnym cierpieniem związanym ze śmiercią ${ }^{19}$. Zmuszeni do przekazania faktu śmierci używają eufemizmów i metafor zaśnięcia, wyjechania czy „zabrania przez aniołki”. Najnowsze badania potwierdzają jednak, że dzieci nie tylko rozumieją śmierć, ale mają także świadomość własnego końca ${ }^{20}$. Na błąd nieuprawnionego przypisywania dzieciom nieświadomości śmierci wskazuje E. Kübler-Ross. W książce poświęconej umieraniu najmłodszych wskazuje, że dzieci są w stanie zrozumieć śmierć, a nierzadko wiedzą o niej więcej niż dorośli. „Dzieci wiedzą (nie świadomie, lecz intuicyjnie), jaki będzie koniec ich choroby. [...] Wszyscy mali pacjenci czują na duchowym, a nie intelektualnym poziomie, że śmierć jest bliska. Zdarza się, że pytają — „Czy ja umrę mamo?" "21. Choć dzieci nie myślą jak dorośli i nie pojmują śmierci abstrakcyjnie ( $w$ rozwoju dzieci zauważalny jest zmienny w czasie sposób pojmowania zjawiska śmierci $-\mathrm{w}$ wieku 3-5 lat śmierć jawi się im jako coś tymczasowego

16 B. Bettelheim, Cudowne i pożyteczne: o znaczeniach i wartościach baśni, Warszawa 1996, s. 28.

17 B. Kędzierska, Dziecko wobec nieuleczalnej choroby i śmierci, [w:] Pediatryczna opieka paliatywna, red. A. Korzeniewska-Eksterowicz, W. Młynarski, Łódź 2011, s. 423.

18 J. Korczak, Prawo dziecka do szacunku, Warszawa 2012, s. 191.

19 B. Kędzierska, op. cit., s. 424-425.

20 Zob. ibidem, s. 424.

${ }^{21}$ E. Kübler-Ross, Dzieci i śmierć, przeł. M. Gajdzińska, Poznań 2007, s. 22. 
i jednoznacznie odwracalnego, w wieku ok. 5 lat zaczynają rozumieć, że wiąże się ona z niemożliwością powrotu do życia, a ok. 8 roku życia dochodzą do dorosłego rozumienia śmierci ${ }^{22}$ ) nie oznacza to, że nie potrafią one logicznie i racjonalnie wytłumaczyć sobie pewnych zjawisk czy zależności. $\mathrm{W}$ ich rozumowaniu rzeczywistość miesza się jednak z fantazją i marzeniami. Mimo że w rozmowach z dziećmi zadaniem rodziców jest weryfikowanie i oddzielanie prawdy od fikcji, to ten dziecięcy wymiar fantazjowania może być bardzo pomocny, jeżeli chcemy przekazać dziecku niełatwe tematy ${ }^{23}$. Zatem nie powinniśmy się zastawiać nad tym, „czy” poruszać z dziećmi tematykę tanatologiczą, a w zamian odpowiedzieć sobie na pytanie „jak” rozmawiać24.

\section{Bajkowa śmierć — rola biblioterapii w rozmowach o śmierci}

Pomocna może okazać się biblioterapia. Jako metoda psychoterapeutyczna ma za zadanie wzmocnić i wzbogacić zasoby pacjenta, by mógł lepiej radzić sobie z trudnościami oraz wypracować sposób radzenia sobie $\mathrm{z}$ nimi ${ }^{25}$. W baśniach, bajkach (czy wyodrębnianych bajkach terapeutycznych) dzieci mogą odnaleźć cząstkę siebie, utożsamić się z bohaterem, doświadczyć tego, co on, a nawet się na nim wzorować. Odpowiadania dostarczają także gotowych wskazówek, jak dziecko może poradzić sobie z problemem oraz jak poradzić sobie w bezprecedensowej sytuacji. Dzięki opowiadaniom można dotrzeć do przeżyć dziecka, znaleźć dostęp do emocjonalnych problemów, pomóc w samopoznaniu ${ }^{26}$, zdefiniowaniu własnych lęków oraz odniesieniu ich do przeżywanej przez dziecko sytuacji. Igor Borkowski, powołując się na Hannę Diduszko, stwierdza, że autorzy książek dla najmłodszych dostrzegli fakt dziecięcego zainteresowania śmiercią, a literatura powinna podejmować próbę stworzenia dzie-

22 D. Brett, Bajki, które lecza, cz. 1, przeł. M. Trzebiatowska, Gdańsk 2014, s. 170.

${ }^{23}$ M. Fopka-Kowalczyk, Jak rozmawiać z dziećmi o chorobie, cierpieniu i śmierci. Opowiadania i baj$k i$, Warszawa 2017, s. 77-78.

${ }^{24}$ Kübler-Ross podkreśla konieczność gotowości rodziców do podjęcia rozmów na tematy ostateczne. Wskazuje, że dziecko wyczuwające ów brak gotowości będzie nieustannie poszukiwało sposobów wyrażenia swoich emocji. Powiernika będzie szukać w przyjaciołach, opiekunach medycznych czy koledze z sali szpitalnej — w kimś, kto będzie otwarty na zrozumienie ich symbolicznego języka. Może się zdarzyć, że dziecko swoje emocje opisze w formie wiersza lub pamiętnika. Przykładem takich zachowań może być przytaczana przez Kübler-Ross dziecięca poezja, w której autorzy ewidentnie przewidzieli swoją śmierć. Wiersze, listy i opowiadania dowodzą jednocześnie że dzieci mają świadomość śmierci. Autorka opisuje także wiele przypadków swoich pacjentów (podczas rozpoczynającej jej karierę lekarską praktyce w szwajcarskiej prowincji), którzy w snach przewidzieli swoją śmierć lub jeszcze jako dzieci pisali dojrzałe listy pożegnalne. Zob. E. Kübler-Ross, op. cit., s. 145-162.

${ }^{25}$ M. Molicka, Bajkoterapia: o lękach dzieci i nowej metodzie terapii, Poznań 2007, s. 105-104.

26 I. Osuchowska, Wykorzystanie bajek i baśni w psychoterapii dzieci i młodzieży, [w:] Baśn i dziecko, red. H. Skrobiszewska, Warszawa 1978, s. 152. 
ciom płaszczyzny mierzenia się $\mathrm{z}$ tymi problemami ${ }^{27}$. Choć sam termin biblioterapii został użyty dopiero w XX wieku, to pojęcie to sięga starożytności. Już w aleksandryjskiej bibliotece widniały napisy „Lekarstwo na umysł”, a Szeherezada leczyła sułtana z depresji właśnie baśniami. Współcześnie stosowana biblioterapia to „działanie terapeutyczne oparte na wykorzystywaniu materiałów czytelniczych rozumianych jako środek wspierający proces terapeutyczny w medycynie" 28 .

„Arcydzieła literatury dziecięcej nigdy nie unikają dialogu o tzw. trudnych sprawach. Może dlatego są arcydziełami?" 29 . Sieroctwo oraz śmierć to tematy obecne w bajkach od zawsze. Ich autorzy nie unikają "pokazywania śmierci”, co więcej ukazują jej oblicze niespowite w tajemnicę, grozę czy rozpacz. Przypomnijmy, że z powodu nieodwzajemnionej miłości umiera Andersenowska Mała Syrenka, na śmierć zamarza bohaterka Dziewczynki z zapałkami, w powieści Astrid Lindgren samobójstwo popełniają bracia Lwie Serce ${ }^{30}$. U braci Grimm w Wysłannikach śmierci spersonifikowaną śmierć w ludzkim ciele ratuje młody przechodzień, a w Kumie przedstawiona jest ona jako matka chrzestna kolejnego z trzynaściorga dzieci biednego chłopa. Michael Deon w poetyckiej opowieści Tomek i nieskończoność opisuje historię konającego chłopca, który w gorączkowych majaczeniach porzuca realny świat i myślami przenosi się na położoną pośrodku oceanu idylliczną wyspę. Obraz śmierci błogiej, uspokajającej, znajdziemy w takich książkach jak Oskar i Pani Róża Erica Emmanuela Schmitta czy $W$ zwierciadle, niejasno Josteina Gaardera ${ }^{31}$. Oswajanie śmierci zapewnia także Mały Ksiażze - daje do zrozumienia, że śmierć nie jest ostatecznością, ale jedynie zamknięciem pewnego okresu. Śmierć bohatera, choć samobójcza, jest równocześnie obrazem nadziei na spotkanie: „Gdy popatrzysz nocą w niebo, wszystkie gwiazdy będą się śmiały do ciebie [...]. Twoje gwiazdy będą się śmiały”. Mały Książę umiera pogodzony ze światem, bez nienawiści i żalu do świata i człowieka ${ }^{32}$.

Wyraźnie widać, że śmierć i umieranie z jednej strony uznawane za temat tabu, są jednocześnie mocno eksploatowane w dziecięcej literaturze - zarówno w przywołanych literackich klasykach, w ludowych podaniach tudzież w powtarzanych kolejnym pokoleniom bajkach, takich jak Czerwony Kapturek, Królewna Śnieżka czy Śpiąca królewna. Literaturze wtórują adaptacje filmowe i bajki animowane - matka tytułowego jelonka Bambi zostaje zastrzelona, rodziców Tarzana zabija lampart, a w bijącej rekordy popularności wśród dzieci Krainie lodu rodzice Elsy i Anny giną na morzu

${ }^{27}$ I. Borkowski, Dzisiaj oswoimy śmierć. Tanatopedagogiczna literatura adresowana do dzieci na wspótczesnym polskim rynku książki, „Bibliotheca Nostra. Śląski Kwartalnik Naukowy” 2016, nr 1 (43), s. 13, https://www.sbc.org.pl/dlibra/show-content/publication/edition/250775?id=250775 (dostęp: 21.07.2018).

${ }^{28}$ M. Molicka, op. cit., s. 103.

${ }^{29}$ G. Leszczyński, Książki pierwsze. Książki ostatnie? Literatura dla dzieci i młodzieży wobec wyzwań nowoczesności, e-book, Warszawa 2012, s. 19.

${ }^{30}$ Ibidem, s. 20.

31 Ibidem, s. 93.

32 Ibidem, s. 94. 
w pierwszych scenach animacji. Należy wspomnieć także o krótkich opowiadaniach tj. Bajka o włosie Patryku, Tomek i nieskończoność, Wieczny kwiat, Gęś, śmierć i tulipan, Siedem sowich piór czy Bajka o liściu Jasiu, które prostymi metaforami obrazują tematy przewlekłej choroby, śmierci i przemijania. W prosty, bezceremonialny, zrozumiały i bezpieczny dla dziecka sposób przedstawiają łatwo przyswajalny symboliczny wymiar świata. Przedstawiona w bajkach śmierć nie jest bezsensowna i nie jawi się jako zagłada, ostateczny koniec czy kara. „Z chorobą jest tak jak ze śmiercią. Jest faktem. Nie jest żadną karą" ${ }^{33}$.

Pojawiającą się w dziecięcej literaturze metaforyka staje się kluczem do przekazania trudnych prawd związanych z przemijaniem ${ }^{34}$. Bajka może stanowić preludium do rozmów na tematy niełatwe zarówno dla dziecka, jak i dorosłego. Jest pomocą w samodzielnym i twórczym radzeniu sobie w świecie, doskonaleniu w sobie umiejętności rozwiązywania problemów - najpierw w sferze wyobraźni, potem w rzeczywistości ${ }^{35}$. Biblioterapia może stać się jedną z najefektywniejszych metod leczenia pacjentów objętych opieką paliatywną i chorych terminalnie, którzy nieuchronnie zbliżają się ku śmierci, a przywrócenie somatycznego stanu zdrowia (poprzez leczenie objawowe) staje się najczęściej niemożliwe.

\section{Kulturowe zaprogramowanie — rola scenariuszy kultury w procesie umierania}

Bajki będące rezerwuarem symboli i łatwo przyswajalnych metafor są także jedną z nielicznych przestrzeni, gdzie zachowała się obrzędowość ludzkich zachowań. Jednym z najczęściej spotykanych bajkowych rytuałów jest metaforyczny obrzęd przejścia. Wskazanie zachowań rytualnych jest proste w odniesieniu do społeczności plemiennych, jednak wyodrębnienie poszczególnych obrzędów przejścia w społeczeństwach poindustrialnych staje się niemałym problemem. Sylwia Jaskulska, powołując się na Jeana Maisonneuve, Jacka D. Ellera oraz Arnolda van Gennepa ${ }^{36}$, stwierdza, że rytuałem może być „wszystko i nic”, a ludzie mogą podchodzić w sposób zrytualizowany do wszystkiego. Rytuały dotyczą wszystkich dziedzin życia, w których pojawia się zmiana (może to być fizyczna zmiana zamieszkania, jak i ta o wymiarze

33 É.E. Schmitt, op. cit., s. 66.

${ }^{34}$ I. Borkowski, op. cit., s. 16.

${ }^{35}$ M. Molicka, op. cit., s. 8.

36 Za twórcę trójstopniowego rytuału przejścia uznaje się Arnolda van Gennepa. Obrzędy rytualne badacz postrzegał jako elementy podtrzymujące społeczeństwo i zapewniające ciągłość jego doświadczeń. Obrzędy przejścia pojmował jako zmianę, która może dotyczyć każdej sfery ludzkiego życia, zarówno sacrum, jak i profanum. Zob. A. van Gennep, Obrzędy przejścia. Systematyczne studium ceremonii, przeł. B. Biały, Warszawa 2006. 
społecznym, np. zaślubiny) $)^{37}$. W każdej z nich pojawia się taki sam scenariusz rite de passage, który zdaniem van Gennepa składa się z trzech następujących po sobie sekwencji. Cykl rozpoczyna rytuał wyłączenia jednostki z jej dotychczasowego stanu, środowiska, po tym następuje faza tzw. okresu przejściowego, marginalnego, podczas którego jednostka jest czasowo pozbawiona statusu. Rytuał kończy się procesem włączenia, integracji, którego celem jest przysposobienie nowego statusu ${ }^{38}$.

Jaskulska, powołując się na prace antropologów, stwierdza, że wspólnymi cechami wszystkich rytuałów jest ich powtarzalność, sformalizowanie, skonwencjonalizowanie, standaryzacja. Rytuały są symboliczne mają swoją treść i strukturę. Ich celem jest podtrzymanie ładu społecznego, przysposobienie do nowej roli oraz panowanie nad wynikającym ze zmian strachem ${ }^{39}$. Stwierdza także, że to właśnie bajki są „cudowną przechowalnią i używalnią rytuałów przejścia”. Przytacza rozważania Grzegorza Leszczyńskiego, który twierdzi, że w bajkach można wyróżnić dwie przestrzenie przejść rytualnych - drogę, którą pokonuje bohater oraz towarzyszącą mu pozatekstową przestrzeń doświadczeń czytelnika. Autorka artykułu o współczesnych rytuałach przejścia stwierdza, że dzięki symbolicznej wędrówce z bohaterem, czytelnik może przeżywać rożne zachowania, pozostając w bezpiecznej przestrzeni fikcji literackiej. Zyskuje także doświadczenia, które ubogacają świat jego emocji. Obcując z baśniami, dokonujemy „własnych przejść" lub w świetle przesłania baśniowego na nowo postrzegamy własne doświadczenia zmiany ${ }^{40}$. Dzieci słuchające opowieści nierzadko utożsamiają się z bohaterem, równolegle przeżywając z nim jego przygody. Obserwują jego zmagania z problemem, podświadomie zyskując wiedzę, jak rozwiązać własny problem. Zauważają także, że przeżywane trudności nie dotyczą tylko ich.

Możemy sobie tego nie uświadamiać, ale cała nasza kultura ma charakter zrytualizowany, ponieważ jej podstawą jest to, że ludzie znają i robią odpowiednie rzeczy w odpowiednich sytuacjach społecznych ${ }^{41}$, powielają pewne utarte schematy, często nawet nie zdając sobie sprawy, że owe schematy istnieją (i że działają według wzorca). Społeczeństwo dysponuje ugruntowanymi scenariuszami postępowania, które nazywamy scenariuszami kultury, a dzięki zakorzenionym w kulturze wzorcom zachowuje ciągłość doświadczeń przez kolejne pokolenia. Dalsze spostrzeżenia oparte są na pojęciu scenariuszy kultury stworzonym przez Aleksandra Woźnego.

37 S. Jaskulska, Wspótczesne rytuały przejścia z dzieciństwa do dorosłości: baśń o Śpiącej Królewnie, [w:] Bajka, baśń, legenda i mit w naukowych opracowaniach, red. A. Grabowski, M. Zaorska, Olsztyn 2016, s. 45-47.

38 J. Tokarska-Bakir, Przemiany, [w:] Obrzędy przejścia. Systematyczne studium ceremonii, red. A. van Gennep, Warszawa 2006, s. 7-9.

39 S. Jaskulska, op. cit., s. 45-56.

${ }^{40}$ Ibidem, s. 47.

41 J.D. Eller, Antropologia kulturowa. Globalne sity, lokalne światy, przeł. A. Gąsior-Niemiec, Kraków 2012, s. 353. 
Scenariusz kulturowy to matryca regulująca zachowania komunikacyjne uczestników kultury. Charakteryzuje je perspektywa długiego trwania w rozumieniu Fernanda Braudela - są powtarzalne, stabilne, a dzięki temu przewidywalne. Woźny, powołując się na orkiestralną teorię komunikacji stworzoną przez Yves’a Winkina, stwierdza, że ważniejsze od samego przekazu jest jego kulturowe uwarunkowanie. Społeczeństwo całkiem nieświadomie odtwarza wzory i zachowania komunikacyjne utrwalone w kulturze. Na dowód swojej tezy jako jeden z takich scenariuszy Woźny wskazał itineraria, czyli perygrynacyjne relacje tworzone w czasach starożytnych i średniowiecznych, które odnowione przez słuchaczy polskiej sekcji Radia Watykańskiego, można odnaleźć w czasie stanu wojennego. W kolejnej, autorskiej publikacji badacz analizuje podobny scenariusz w telewizyjnych serwisach informacyjnych, realizowanych po katastrofie smoleńskiej ${ }^{42}$.

Odgrywane zgodnie z respektowanymi wartościami interakcje umacniają wspólnotę, zapewniają jej ład i trwałość, przekazywanie tradycji, doświadczeń i wiedzy. Owe scenariusze przypominają orkiestrę, w której dyrygent i partytura są zbędne, bo każdy doskonale zna odgrywaną przez siebie partię ${ }^{43}$. Człowiek jest istotą społeczną należącą do sfery wspólnoty, która to z kolei podlega nieustannemu potwierdzaniu $\mathrm{w}$ komunikowaniu się z innym oraz interpretacji przekazów symbolicznych ${ }^{44}$. Treść i informacja są nieodzowne, ale pierwsze skrzypce grają kontekst i znaczenie. Na dowód tego Woźny przytacza stwierdzenie Winkina, że „partytura, którą otrzymał [uczestnik komunikacji - przyp. K.P.] jest bardzo złożona, tworzy ona w rzeczy samej muzykę, a nie proste dźwięki” ${ }^{45}$, dlatego cała komunikacja jest dla uczestników kultury rozpoznawalną „melodią". Scenariusz kulturowy to kontekstowe ujmowanie komunikacji. Pojedyncze komunikaty wpisują się w szerszą matrycę, która stanowi komunikację społeczną, a więc zespół kodów i reguł, które umożliwiają interakcje i relacje między uczestnikami tej samej kultury, nadając jej regularność i przewidywalność ${ }^{46}$.

Wrocławski medioznawca przytacza także głęboką metaforę stworzoną przez Winkina, a mianowicie porównanie komunikacji do gry w piłkę. Stwierdza, że musimy dostrzec nie tyle samą piłkę, czyli poszczególny komunikat, ile trajektorię jej lotu, a więc społeczny kontekst komunikacji. Dzięki temu będziemy w stanie śledzić boisko i reguły realizowane przez grających, bez angażowania się w obserwację lotu

${ }^{42}$ M. Rydlewski, A. Woźny, Antropologia historyczna Piotra Kowalskiego a wrocławski projekt antropologii mediów, „Rocznik Antropologii Historii” 2017, nr 10, s. 60.

${ }^{43}$ A. Woźny, Przewodnicy - mistyfikatorzy - heretycy. Studia z antropologii komunikacji i mediów, Wrocław 2016, s. 191.

${ }^{44}$ A. Woźny, Media i kryzysy - komunikacja alternatywna, [w:] Powodzie, plagi, życie i inne katastrofy, red. K. Konarska, Wrocław 2012, s. 265.

${ }^{45}$ A. Woźny, Media..., s. 264; cytat za: Y. Winkin, Antropologia komunikacji. Od teorii do badań terenowych, przeł. A. Karpowicz, Warszawa 2009, s. 75.

${ }^{46}$ A. Woźny, Przewodnicy..., s. 11. 
piłki ${ }^{47} \mathrm{w}$ efekcie czego będziemy mogli przewidzieć, jak potoczy się mecz. Zrozumienie komunikacji gwarantuje jej uczestnikom zrozumienie całego kontekstu, którego nośnikiem a zarazem tworzywem (ale też i efektem) jest kultura. Stąd tak istotne jest analizowanie struktur długiego trwania.

Kulturalną determinację komunikacji podkreśla także Janina Hajduk-Nijakowska, która stwierdza, że jesteśmy niejako kulturowo zaprogramowani na sposób przyjmowania i tworzenia informacji. Opierając swoje spostrzeżenia na tezach wybitnego socjologa Roberta K. Merona, zauważa, że w zachowaniach społecznych powielamy realizowany już kiedyś sposób postępowania, a raz przypisane znaczenie warunkuje późniejsze postawy i czyny ${ }^{48}$. Takim zaprogramowaniem jest scenariusz kultury Woźnego. Przywoływane już bajki terapeutyczne mogą okazać się nie tyko rezerwuarem zanikającej obrzędowości, ale stać się również jednym ze scenariuszy kultury dla chorych terminalnie dzieci i ich rodzin. Opowiadania są dla dzieci łatwą do zrozumienia „matrycą", dostarczają wzorów zachowań, powielają wzory, formy opowiadania i metafory uprzednio zakorzenione w kulturze (powtarzalne są także występujące w nich konstrukcje narracyjne i formy językowo-stylistyczne) ${ }^{49}$. Za jeden ze scenariuszy szeroko eksploatowanych w bajkach możemy uznać scenariusz przebudzenia — rytuał wiążący się ze zmianami, o które nietrudno w chorobie terminalnej.

Bajki jako osobliwe scenariusze kultury dostarczają bezpiecznych wzorów zachowań, cechuje je rytualna przewidywalność, dzięki czemu nawet najtrudniejsze tematy, tj. śmierć i umieranie, tracą swój dramatyzm. Kontekstowość i konwencjonalność pozwala na rozumienie używanych metafor, dzięki którym np. za pomocą cyklu życia rośliny i jej naturalnemu (niebudzącym aż tak wielkich emocji) obumieraniu, więdnięciu można obrazowo mówić o śmierci.

W bajkach terapeutycznych przeżycia głównego bohatera bardzo często przedstawiane są na gruncie jednego ze scenariuszy kultury, który Woźny określa scenariuszem przebudzenia ze strukturyzującym go rite de passage: „rodzaj kulturowej matrycy, która pojawia się, gdy zawodzi zrozumiała struktura świata, gdy konieczne staje się zerwanie $\mathrm{z}$ dotychczas obowiązującymi zasadami działania i myślenia - bo przecież »odtąd już nic nigdy nie będzie tak samo «" 50 . Woźny zainspirowany antropologią Yves’a Winkina, Ervinga Goffmana, Della Hymesa i Piotra Kowalskiego przywołuje stworzony przez Arnolda van Gennepa obrzęd przejścia. Gennep pojmował rytuał jako mechanizm podtrzymujący ciągłość społeczną i odzwierciedlający kulturę. Kontynuator jego teorii - Victor Turner dostrzegł w rytuałach rezerwuar

47 A. Woźny, Odtąd już nigdy nie będzie tak samo. Media, kryzysy, eventy... i peryferie, Wrocław 2013, s. 79.

48 J. Hajduk-Nijakowska, Katastrofa jako wydarzenie medialne, „Colloquia Anthropologica et Communicativa" 5. Powodzie, plagi, życie i inne katastrofy, red. K. Konarska, P. Kowalski, Wrocław 2012, s. 239 .

49 A. Woźny, Odtąd..., s. 43-44.

${ }^{50}$ M. Rydlewski, A. Woźny, op. cit., s. 63. 
symboli będących nośnikiem wspólnotowych wartości. Według niego rytuał nie tylko potwierdza i odzwierciedla rzeczywistość, ale wprost ją generuje i przekształca ${ }^{51}$.

Powołując się na teorię scenariuszy Woźnego oraz konstatację Turnera o sprawczej sile rytuałów, zakładam, że hospicjum może być rozpatrywane poprzez pryzmat przejścia ewokowanego w scenariuszu przebudzenia. W związku z poddaniem się opiece hospicyjnej (mam tu na myśli oddziały stacjonarne) zmienia się miejsce pobytu jednostki, jej hierarchia grupowa, role społeczne, zmienia się całe życie chorego i jego rodziny. Nie można pominąć tu także istotnych zmian mentalnych.

Diagnoza choroby oraz podjęcie decyzji leczenia jest pierwszą fazą rytuału, w której następuje wyłączenie chorego z jego dotychczasowej roli. Traci on status osoby zdrowej. Nierzadko następuje też degradacja jego ról społecznych związana wpływem choroby - utrata pracy, niemożność wykonywania dotychczas pełnionych obowiązków. Rak stygmatyzuje chorego, który często jest wykluczany ze społeczeństwa ${ }^{52}$.

Jechałam samochodem i zanosiłam się płaczem, ale myślałam o mojej młodszej córce, z którą mieszkałam, ponieważ starsza wyjechała. Nie miałam pomysłu, jak jej to powiedzieć. Siedziałam w pracy, głowę schowałam w dłoniach i łzy mi skapywały wolno... Wróciłam do domu i grałam jakąś rolę, zupełnie nie byłam sobą. Nie mogłam dojść do ładu. Nie mogłam jej o tym powiedzieć, ostatecznie, nie pamiętam jak to się stało ${ }^{53}$.

W pierwszych chwilach po konfrontacji z wyrokiem następuje pełen emocji okres, który Woźny, za Turnerem, określa „tunelem z tajemniczą naturą". Tunel jest metaforą przejścia drogą, w której nie wiadomo, co może czekać chorego ${ }^{54}$. Jest to okres buntu, sprzeciwu, zwątpienia. Chory może skutecznie zaprzeczać swojej roli, zadaje pytanie, „dlaczego ja?”, nierzadko traci nadzieję i poddaje się. W tym momencie istotna jest pomoc psychologiczna i wsparcie duchowe, które pozwolą choremu na rytuał obmycia się, dzięki któremu możliwe będzie rozpoczęcie trzeciej fazy - włączania do nowej wspólnoty chorych. Pogodzenie się z rzeczywistością i nową rolą oraz mimo wszystko koniecznością dalszej walki z chorobą.

Poetycki, pełny metafor obraz rytuału przejścia, w którym można dostrzec realizację rite de passage dostarcza krótka bajka Jesień liścia Jasia. Opowiadanie amerykańskiego autora o prozaicznym temacie i nieco infantylnym tytule jest głęboką refleksją na temat ludzkiego życia. Podtytuł Opowieść dla dużych i małych podkreśla, że jest to pozycja skierowana zarówno dla dzieci jak i dorosłych, zapewniająca życiową lekcję w sposób wykraczający poza granice wieku.

51 S. Jaskulska, „Rytuał przejścia” jako kategoria analityczna. Przyczynek do dyskusji nad badaniem rytualnego oblicza rzeczywistości szkolnej, „Studia Edukacyjne” 2013, nr 26, s. 81.

52 S. Sontag wprost nazywa raka chorobą „zakaźną moralnie”.

${ }^{53}$ Wypowiedź uczestniczki badań, Choroba nowotworowa - doświadczenia pacjentów. Raport na zlecenie AXA Życie i Społecznej Fundacji Ludzie dla Ludzi, Warszawa 2014, s. 18, http://www.ludziedlaludzi.pl/database/uploads/file/Choroba\%20nowotworowa\%20-\%20do\%C5\%9Bwiadczenia\%20pacjent\%C3\%B3w.pdf (dostęp: 3.07.2018).

54 A. Woźny, op. cit., s. 10. 
Całe opowiadanie można uznać za cenny scenariusz kultury, który (tak jak inne bajki terapeutyczne) może być dla dziecka receptą na poradzenie sobie z problemem zbliżającej się śmierci. Doktor psychologii klinicznej dziecka Maria Molicka wprost stwierdza, że bajki terapeutyczne leczą i pomagają radzić sobie z lękiem i są niezastąpioną pomocą w samodzielnym radzeniu sobie $\mathrm{w}$ świecie ${ }^{55}$.

Tytułowego Jasia poznajemy jako jednego z wielu zdrowych liści dużego klonu ${ }^{56}$. Jaś dorasta radośnie wśród swych roślinnych współtowarzyszy. Przeżywając kolejne dni, poznaje też swojego najlepszego przyjaciela - Daniela. „Jaś był pewien, że na całym konarze nie ma liścia mądrzejszego niż Daniel”57. To waśnie jego Jaś uznał za swojego nauczyciela, który nauczył go wiele o życiu i przygotował do jesiennego opadnięcia na ziemię.

Wyboru tego opowiadania dokonałam ze względu na jego głęboką metaforykę. Uważam także, że w zachowaniu Jasia można zauważyć realizację scenariusza przebudzenia. Zaletą przedstawienia umierania jako metafory opadania liści drzewa jest nie tylko uniknięcie mówienia o śmierci wprost. Animizacja ta jest także zapowiedzią nowej nadziei. Po martwej zimie nastanie dla drzewa pełna życia wiosna.

Metaforyczny jest już sam tytuł i zaakcentowanie jesieni — pory roku, która jest symbolem dojrzałości, spowolnienia aktywności życiowej, zasłużonego odpoczynku po trudach życia. Potocznie używamy określeń takich jak „złota jesień”, „jesień wieku”, aby eufemistycznie określić starość. Jesień to czas na odpoczynek i podsumowania swojego życia oraz przygotowania się do śmierci. Taka też jest jesień w omawianej książce.

„Wiosną listki uczyły się tańczyć w powiewach lekkiego wietrzyka, latem - wygrzewały się leniwie w promieniach słońca, a później chłodziły się w strugach deszczu" ${ }^{\prime 2}$. Kolejne metaforyczne ujęcie uświadamia, że każdy okres życia ma inny charakter i priorytety. Po beztroskiej młodości listki zaczęły powoli dojrzewać, z czasem pozwalając sobie na coraz większe lenistwo, a więc mniejszą aktywność. Kolejno przyszedł czas na pierwsze jesienne chłody i deszcze, a więc starość i stagnację. Daniel, w którym Jaś upatrywał swojego przyjaciela, był dla niego także przewodnikiem życia - opowiadał o słońcu, ptakach, porach roku. Wytłumaczył Jasiowi jego przeznaczenie i uświadomił, że wszystkie liście są jedynie częścią drzewa, a każdy z nich jest niepowtarzalny. Można w tym doszukać się pewnego zabiegu biblioterapeutycznego - dziecko, utożsamiając się z Jasiem, uświadomi sobie, że tak jak Jaś jest na swój sposób wyjątkowy, wyjątkowa jest także jego choroba.

55 M. Molicka, op. cit., s. 8.

56 Znaczący jest tu także wybór gatunku drzewa. To właśnie drewno klonowe służyło najczęściej do sporządzania trumien. Wierzono, że klon posiada moc odpędzania złych mocy i dlatego układano niegdyś na surowym drewnie, ostruganym do czysta, ludzi umierających, aby ulżyć im w cierpieniu, albo już zmarłych, w celu przygotowania do pogrzebu — stąd wzięło się powiedzenie „do grobowej deski”.

57 L.F. Buscaglia. Jesień liścia Jasia: opowieść o życiu dla małych i dużych, Gdańsk 2012, s.12.

58 Ibidem. 
„Ale lato Jasia szybko minęło" 59 - ta konstatacja wprowadza w pierwszą fazę rite de passage Szron, który symbolizuje tu pierwsze oznaki choroby, niejako wyłącza listki z ich dotychczasowej roli, czego widoczną oznaka jest zmiana koloru. Kolejne pytania o kolor, o to, co się dzieje, zwątpienie, bunt i strach są charakterystyczne dla fazy marginalnej. Jaś zastanawia się, dlaczego każdy listek ma inny kolor, skoro wszystkie są częścią tego samego drzewa, przeraża go to, czego on i inne listki doświadczają, boi się. Stanowi to ciekawe odniesienie do sytuacji dzieci w pierwszych dniach pobytu w szpitalu lub hospicjum. Chore dzieci podobnie jak listki są wyrwane ze swojego dotychczasowego życia, tak jak kolor liści, tak też zmienia się ich ciało i samopoczucie, podobny jest także towarzyszący dzieciom strach. Choroba wiąże się także ze zmianą stylu życia, a w związku z podjęciem opieki paliatywnej, dzieci zmuszone są do rezygnacji z uczestnictwa w szkolnych zajęciach. Feeria kolorów korony drzewa obrazuje zróżnicowanie jednostkowego przeżywania i objawów choroby u każdego dziecka. Po usłyszeniu diagnozy dzieci szczególnie potrzebują pomocy i obecności drugiej osoby — kogoś, kto wytłumaczy i pomoże w przejściu trudnej drogi. Wzorem dla rodziców i opiekunów może być postać Daniela, który ze spokojem wyjaśnia Jasiowi, że każdy listek ma inne doświadczenia, które przekładają się teraz na ich barwy. Daniel nie okłamuje Jasia i wprost stwierdza, że całe drzewo przeżywa jesień, czyli czas, „kiedy liście przeprowadzają się do innego domu. Niektórzy nazywają to umieraniem"60.

Jaś buntuje się przeciw śmierci. $Z$ dziecięcą jeszcze ciekawością zadaje pytanie, czy wszyscy umrą i kiedy to się stanie oraz co nastąpi po śmierci. Daniel ze stoickim spokojem odpowiada na każde jego pytanie, nie ukrywając rzeczywistości. Godną naśladowania jest także reakcja na jednoznaczne stwierdzenie Jasia, że boi się śmierci:

Boję się umrzeć - powiedział Jaś.

— Nie wiem, jak jest tam, na dole. — Wszyscy się boimy tego, czego nie znamy, Jasiu. To jest zupełnie naturalne - zapewnił Daniel — A jednak nie bałeś się, kiedy wiosna zamieniała się w lato. Nie bałeś się, kiedy lato zamieniało się w jesień. To były naturalne zmiany. Czemu więc miałbyś się bać teraz, kiedy nadchodzi pora śmierci?"61.

Skierowanie uwagi na to, co dzieci przeżyły, co sprawiało, że były szczęśliwe, oddala lęk śmierci. Daniel uświadamia też Jasia, że opadanie liści nie oznacza całkowitego końca i „jest coś silniejszego od drzewa. To życie. Ono jest wieczne, a my wszyscy jesteśmy częścią życia”. Daniel w kilku prostych słowach, bez rozpaczy, lęku, zawiłych sformułowań czy unikania tematu uświadomił Jasiowi, że śmierć nie jest ostatecznością. Prozaiczne, może wręcz banalne, opowiadanie jest jednak idealne w swej prostocie - bez zbędnego patosu czy waty słownej uświadamia, że śmierć nie jest tożsama $\mathrm{z}$ definitywnym końcem i jest tylko przejściem do nowego etapu.

\footnotetext{
59 Ibidem, s. 20.

60 Ibidem, s. 28.

61 Ibidem, s. 34.
} 
Po początkowym buncie młodego liścia, następuje powolne oswajanie się z śmiercią, Jaś jest świadkiem odejścia swojego mentora: „Opadał bez najmniejszego wysiłku. Wydawało się, że lecąc, uśmiecha się spokojnie. - Na razie, Jasiu. Do widzenia! — zawołał"62. Czytelnik nie jest w tym momencie świadkiem histerii i rozpaczy. Jaś podchodzi do tego wydarzenia spokojnie i dojrzale. Po akceptacji trudnej rzeczywistości następuje czas zrozumienia. Dzięki rozmowom Jaś wkracza w trzecią fazę rite de passage, którą można uznać za pogodzenie się ze śmiercią i procesem umierania. Towarzyszy jej spokój i zrozumienie tego, co dzieje się wokół. Każdego dnia jest świadkiem opadania kolejnych listków. Drzewo ogołaca się coraz bardziej, a Jaś doświadcza coraz większych mrozów i śniegu. Mimo tego jest dzielny, nie okazuje emocji. W końcu: „O świcie nadleciał wiatr i zerwał Jasia z gałęzi. To wcale nie bolało. Jaś popłynął w dół cichutko, delikatnie i miękko"63. Kolejna metafora, dzięki której dziecko uświadamia sobie, że śmierć nie jest czymś bolesnym, przerażającym. Czymś, czego należy się obawiać. Także dalszy metaforyczny obraz może być dodatkowym wsparciem w umieraniu i przygotowaniu się na śmierć, która sama w sobie stanowi piękne wydarzenie:

Kiedy opadał, po raz pierwszy w życiu zobaczył swoje drzewo w całości. Jakże było mocne, jakże potężne! Jaś był pewien, że drzewo będzie żyło bardzo długo. Poczuł dumę na myśl, że on sam był częścią życia tego drzewa. Wylądował na kopczyku śniegu. Było mu miękko, a nawet ciepło. W tej nowej pozycji poczuł się swobodniej niż kiedykolwiek przedtem. Zamknął oczy i zasnął... ${ }^{64}$

Zaledwie kilkustronicowe opowiadanie zostało uznane za bestseller sprzedawany w milionowych nakładach. Prostota przełożyła się na jej pozytywny odbiór, a książka została przetłumaczona na kilkanaście języków. Metafora cyklu życia drzewa może zostać wykorzystana jako wstęp do niełatwej rozmowy o śmierci. Dzieci zapewne rozpoznają w Jasiu wiele cech wspólnych - tak jak on radośnie przeżywały swoje dzieciństwo, wesoło się bawiły, miały dużo kolegów. Odnajdywanie wspólnych cech zapewne ułatwi utożsamienie się z bohaterem, a Jaś stanie się dla dzieci wzorem, który może pomóc w zrozumieniu choroby i oddaleniu lęku śmierci.

Spokojna śmierć Jasia jest dowodem, że dziecku należy powiedzieć prawdę, nie ukrywając przed nim faktu śmierci. Daniel wprost oznajmił, że listki umrą. Mimo drastyczności i dramaturgii takiego przekazu, emocji z nim związanych i początkowego buntu dziecko może lepiej zrozumieć swoją chorobę i przygotować się do śmierci. Świadomość własnej sytuacji mimo nieoptymistycznego końca uspokaja dziecko, które nierzadko z radością przeżywa swoje ostanie chwile. W hospicjach dla dzieci niemal na każdym kroku napotykałem wiarę w jakieś potem. Tu nawet słownictwo wyraża nadzieję na trwania poza śmiercią ${ }^{65}$.

\footnotetext{
62 Ibidem, s. 37.

63 Ibidem.

${ }^{64}$ Ibidem, s. 38.

65 A. Wilowski, op. cit., s. 20.
} 
Antropologia medyczna jest dowodem wielowymiarowości ludzkiej kondycji oraz tego, że choroba ma nie tylko wymiar fizyczny. Już Kant zauważył, że lekarze błędnie zakładają, iż wiele pomogli choremu, bo potrafili nazwać chorobę. Kompleksowe leczenie to dostrzeżenie oprócz somatycznych objawów także subiektywnego postrzegania swojej choroby oraz łagodzenie cierpień duchowych pacjenta. Holistyczne podejście jest szczególnie istotne w opiece paliatywnej, która nastwiona jest nie tyle na wyleczenie, co na poprawę jakości życia chorych. Na takie systemowe podejście pozytywnie wpływa również rozmowa z pacjentem. Zwłaszcza jeśli mamy do czynienia $\mathrm{z}$ przewlekle chorymi. Jak wykazano $\mathrm{w}$ artykule, takich rozmów nie można unikać w przypadku umierających dzieci. Ciężko jest mówić o śmierci explicite, dlatego jednym z efektywnych i odpowiednich dla dziecięcej psychiki sposobów jest odwołanie się do bajek terapeutycznych. Obrazowo, nie wprost, bez zbędnego patosu i tragizmu — omówiona krótka bajka o liściu poprzez szereg metafor śmierci może stanowić łatwy (dla dzieci, jak i dorosłych) sposób przekazania prawdy o śmierci. Dzięki nieświadomemu odgrywaniu wykorzystanych w opowiadaniu scenariuszy kultury, dzieci słuchające bajki oswajają się z tematem śmierci, zyskują wzór postępowania w nowej sytuacji oraz uświadamiają sobie, że nie są same z własnym problemem.

\section{Bibliografia}

Bettelheim B., Cudowne i pożyteczne: o znaczeniach i wartościach baśni, Warszawa 1996.

Borkowski I., Dzisiaj oswoimy śmierć. Tanatopedagogiczna literatura adresowana do dzieci na wspótczesnym polskim rynku książki, „Śląski Kwartalnik Naukowy” 2016, nr 1 (43), https://www.sbc.org.pl/ dlibra/show-content/publication/edition/250775?id=250775 (dostęp: 21.07.2018).

Brett D., Bajki, które leczą. Część 1, przeł. M. Trzebiatowska, Gdańsk 2014.

Buscaglia L.F., Jesień liścia Jasia: opowieść o życiu dla małych i dużych, przeł. E. Wojtych, Gdańsk 2012. Choroba nowotworowa - doświadczenia pacjentów. Raport na zlecenie AXA Życie i Społecznej Fundacji Ludzie dla Ludzi, Warszawa 2014, http://www.ludziedlaludzi.pl/database/uploads/file/Choroba\%20 nowotworowa\%20-\%20do\%C5\%9Bwiadczenia\%20pacjent\%C3\%B3w.pdf (dostęp: 3.07.2018).

Fopka-Kowalczyk M., Jak rozmawiać z dziećmi o chorobie, cierpieniu i śmierci. Opowiadania i bajki, Warszawa 2017.

Grimes R.L., Beggining in Ritual Studies, „Studia Edukacyjne” 2013, nr 26, https://repozytorium.amu. edu.pl/bitstream/10593/10100/1/79-98.pdf (dostęp: 18.07.2018).

Hajduk-Nijakowska J., Katastrofa jako wydarzenie medialne, „Colloquia Anthropologica et Communicativa” 5. Powodzie, plagi, życie i inne katastrofy, red. K. Konarska, P. Kowalski, Wrocław 2012.

Jaskulska S., „Rytuał przejścia” jako kategoria analityczna. Przyczynek do dyskusji nad badaniem rytualnego oblicza rzeczywistości szkolnej, „Studia Edukacyjne” 2013, nr 26, https://repozytorium.amu.edu. pl/bitstream/10593/10100/1/79-98.pdf (dostęp: 18.07.2018).

Jaskulska S., Współczesne rytuały przejścia z dzieciństwa do dorosłości: baśń o Śpiącej Królewnie, [w:] Bajka, baśń, legenda i mit w naukowych opracowaniach, red. A. Grabowski, M. Zaorska, Olsztyn 2016, http://docplayer.pl/25908861-Bajka-basn-legenda-i-mit-w-naukowych-opracowaniach.html (dostęp: 10.07.2018). 
Kędzierska B., Dziecko wobec nieuleczalnej choroby i śmierci, [w:] Pediatryczna opieka paliatywna, red.

A. Korzeniewska-Eksterowicz, W. Młynarski, Łódź 2011.

Korczak J., Prawo dziecka do szacunku, Warszawa 2012.

Kübler-Ross E., Dzieci i śmierć, przeł. M. Gajdzińska, Poznań 2007.

Lakoff G., Johnson M., Metafory w naszym życiu, przeł. T.P. Krzeszowski, Warszawa 1988.

Leszczyński G., Książki pierwsze. Książki ostatnie? Literatura dla dzieci i młodzieży wobec wyzwań nowoczesności, Warszawa 2012.

Molicka M., Bajkoterapia: o lękach dzieci i nowej metodzie terapii, Poznań 2007.

Naumiuk A., O śmierci w procesie wychowania, [w:] Prawda umierania i tajemnica śmierci, red. M. Górecki, Warszawa 2010.

Osuchowska I., Wykorzystanie bajek i baśni w psychoterapii dzieci i młodzieży, [w:] Baśń i dziecko, red. H. Skrobiszewska, Warszawa 1978.

Prognoza ludności na lata 2014-2050, Warszawa 2017, http://stat.gov.pl/ (dostęp: 20.07.2018).

Rydlewski M., Woźny A., Antropologia historyczna Piotra Kowalskiego a wrocławski projekt antropologii mediów, „Rocznik Antropologii Historii” 2017, nr 10.

Schmitt É.E., Oskar i pani Róża, przeł. B. Grzegorzewska, Kraków 2017.

Sontag S., Choroba jako metafora; AIDS i jego metafory, przeł. J. Anders, Kraków 2016.

Wierciński H., Rak: antropologiczne studium praktyk i narracji, Warszawa 2015.

Wierciński H., Stosowana antropologia medyczna, czyli co antropolog może dać lekarzowi, [w:] Antropologia stosowana, Warszawa 2013.

Wilowski A., Weź, pokochaj smoka. Rzecz o umieraniu dzieci, Warszawa 2004.

Woźny A., Media i kryzysy - komunikacja alternatywna, „Colloquia Antropologica et Communicativa” 5. Powodzie, plagi, życie i inne katastrofy, red. K. Konarska, P. Kowalski, Wrocław 2012.

Woźny A., Odtąd już nic nigdy nie będzie takie samo. Media, kryzysy, eventy... i peryferie, Wrocław 2013. Woźny A., Przewodnicy - mistyfikatorzy - heretycy. Studia z antropologii komunikacji i mediów, Wrocław 2016.

\section{The story of autumn as a rite of passage. The role of cultural scripts in making children come to terms with cancer}

\section{Summary}

Illness is a phenomenon that goes beyond its purely medical dimension; its social and cultural aspects are noted more and more often. The turn to medical anthropology discussed in the article as well as contextual approach to communication viewed through culture demonstrate that illness is a phenomenon that should be talked about openly. The research referred to by the author shows that thanatological themes should not be avoided also in conversation with children. Thanks to an analysis of therapeutic tales structured by Woźny's cultural script it has been possible to demonstrate that conversations about death lose their dramatic quality, if they are based on metaphor. A vivid, well-ordered presentation of dying in the form of a metaphor from a tale is one of the ways of teaching children the truth about death. Presenting dying in the form of a ritual is thus a ready-made pattern, i.e. a cultural script.

Keywords: theraphy, medical anthropology, cultural scripts, death 